\title{
How Are the Students' Biology Conceptual Knowledge and Procedural Knowledge in Padang City?
}

\author{
Vina septiani ${ }^{1, *}$ Paidi $^{2}$ \\ ${ }^{1}$ Biology Education, Postgraduate Program, Yogyakarta State University, Jl. Colombo No. 1, Karang Malang, \\ Yogyakarta, 55281, Indonesia \\ ${ }^{2}$ Biology Education, Faculty of Mathematics and Natural Science, Yogyakarta State University, Jl. Colombo No. \\ 1, Karang Malang, Yogyakarta, 55281, Indonesia \\ *Corresponding author. Email: vina11septiani@gmail.com
}

\begin{abstract}
The conceptual knowledge and procedural knowledge are able to equip students to have new skills in the era of the Industrial Revolution 4.0. Because, both of these knowledge are used to solve a problem correctly. This study aimed to determine the conceptual knowledge and procedural knowledge of Biology of grade XI students of state senior high school in Padang, on the subject of human digestive system. This research is quantitative descriptive with survey method. The population was all grade XI students of state senior high school in Padang of 2019/2020 study years. The sampling technique used purposive sampling technique. Data were collected using test instrument to measure the students' conceptual knowledge and procedural knowledge. Data collected was then analyzed by using descriptive statistics. Based on the survey, the ability of the conceptual knowledge of obtain in "bad" category with a range of scores of $0 \leq 21,97<25$. The ability of procedural knowledge of obtain in "bad" category with a range of scores of $0 \leq 22,79<25$.
\end{abstract}

Keywords: The conceptual knowledge, The procedural knowledge, Biology.

\section{INTRODUCTION}

The emergence of the 4.0 industrial revolution created a new face in the phase of technological advancement. In the era of sophisticated technology, knowledge is always increasing every day, and therefore the understanding of the concept of "knowledge" and "science" changes [1]. And these changes also change the skills expected of individuals.

Conceptual knowledge and procedural knowledge are able to equip students to have new skills in the technological era. Because, both of these knowledge are used to solve a problem correctly [2]. Conceptual knowledge is the understanding of definitions, rules, and principles in a field of knowledge, while procedural knowledge is knowledge of specific strategies or actions used to complete tasks and solve problems [3] [4].
According to [3], these two types of knowledge develop in a unidirectional process, the gain in one type of knowledge leads to the improvement of knowledge in another. This is supported by [5] who revealed that increased procedural knowledge supports increased conceptual knowledge and vice versa. As the results of the study [6] showed, initially students' procedural knowledge was higher than conceptual knowledge, but after four months of measurement, the level of attainment of procedural knowledge did not change from the previous one, while conceptual knowledge increased significantly. Therefore, [6] recommends assessing conceptual knowledge and procedural knowledge together.

So far, there have been many measurements of conceptual knowledge and procedural knowledge, but it is more focused on mathematics. Such as research conducted by [7] [8] [9] [10] [11] [12] [13]. There are still few studies that measure both conceptual 
knowledge and procedural knowledge of biology, such as research [14] [15] [16] [17]. To do so, this study is conducted with the objectives formulated as follows:

1. Analyzing the conceptual knowledge of students' biology in Padang city.

2. Analyzing the procedural knowledge of students' biology in Padang city.

\section{METHODS}

\subsection{Research Design}

This research is quantitative descriptive with survey method. The population in this study are hypothetical population that includes all students eleventh grade of state senior high school in Padang. The data collection was conducted on march $2^{\text {nd }}$ to march $31^{\text {th }}, 2020$, the academic year 2019/2020. The sampling technique used purposive sampling technique. The number of sample is 320 students.

\subsection{Research Instrument}

The data were collected through the test technique. The test technique is performed to measure the achievement of conceptual knowledge and procedural knowledge. The instrument test that was used is multiple choice and essay consisting of digestive system material. The instrument has been passing the validity and reliability test. As expressed by [18] that the quality of the instrument compiled can be known by analyzing these instruments, namely in the form of validity and reliability.

\subsection{Data Analysis}

Data collected was then analyzed by using descriptive statistics. Descriptive analysis to find the maximum, minimum, mean, and standard deviation. The determination of the level of the conceptual knowledge and procedural knowledge using the range contained in Table 1.

Table 1. Range of achievement of the ability to biology's conceptual knowledge and biology's procedural knowledge.

\begin{tabular}{cc}
\hline Range of Mean & $\begin{array}{c}\text { Category of Conceptual } \\
\text { Knowledge and Procedural } \\
\text { Knowledge }\end{array}$ \\
\hline$(75) \leq M \leq(100)$ & Very Good \\
$(50) \leq M \leq(75)$ & Good \\
$(25) \leq M \leq(50)$ & Fair \\
$(0) \leq M \leq(25)$ & Bad \\
\hline
\end{tabular}

\section{RESULT AND DISCUSSION}

\subsection{Result}

\subsubsection{The Conceptual Knowledge}

The achievement of students' biology conceptual knowledge in Padang city presented in Table 2.

Table 2. The achievement of students' biology conceptual knowledge in Padang city.

\begin{tabular}{ccc}
\hline Statistics & Score & Category \\
\hline Mean & 21,97 & Bad \\
Standard deviation & 10,491 & - \\
Maximum & 50 & - \\
Minimum & 0 & - \\
\hline
\end{tabular}

The conceptual knowledge of the students at XI grade of state senior high school on digestive system material is 21,97 which belong to the "bad" category (Table 2). The minimum and maximum value ranges from 50 (50-0) with a standard deviation of 10,491 .

\subsubsection{The Procedural Knowledge}

The achievement of students' biology procedural knowledge in Padang city presented in Table 3.

Table 3. The achievement of students' biology procedural knowledge in Padang city.

\begin{tabular}{ccc}
\hline Statistics & Score & Category \\
\hline Mean & 22,79 & Bad \\
Standard deviation & 12,067 & - \\
Maximum & 56 & - \\
Minimum & 0 & - \\
\hline
\end{tabular}

The procedural knowledge of the students at XI grade of state senior high school on digestive system material is 22,79 which belong to the "bad" category (Table 3). The minimum and maximum value ranges from 56 (56-0) with a standard deviation of 12.067 .

\subsubsection{The Conceptual Knowledge VS The Procedural Knowledge}

The comparison of the value of conceptual knowledge and procedural knowledge presented in Figure 1. 


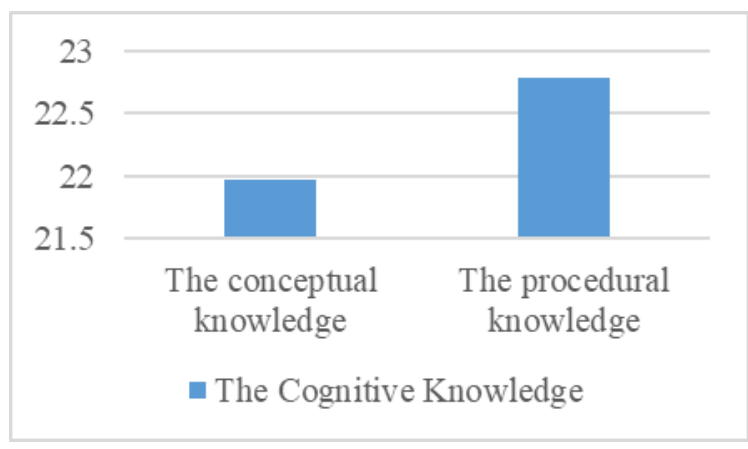

Figure 1. The comparison of the value of conceptual knowledge and procedural knowledge.

Figure 1 shows that the procedural knowledge of students in the city of Padang is higher than conceptual knowledge. Although the difference in value between the two is not too significant, namely 0.82 . However, the value of both knowledge is classified as "bad".

\subsection{Discussion}

Conceptual knowledge and procedural knowledge of biology in the city of Padang are very concerning, where the value of the two knowledge has not reached the limit of the value of the KKM biology in the city of Padang which is 78. Even though these two knowledge are useful in solving problems [2]. Thus, the results of this study become the task for biology teachers, especially in the city of Padang, to improve the quality of learning which has a direct impact on student achievement. As stated by [19], the factors that influence student learning outcomes are the classroom environment which includes: class atmosphere, teaching and learning methods, teacher behavior. Thus it can be understood that teachers are the spearhead of the success of students in the world of education.

To become a competent teacher in teaching, the teacher must have knowledge of the subject matter. Subject matter knowledge is a combination of knowledge of concepts and procedures [20]. So, ideally biology teachers have knowledge of concepts and procedures. As stated by [21] that, the relationship between the two knowledge is two-way. That is, conceptual knowledge supports procedural knowledge and procedural knowledge supports conceptual knowledge [22].

The results of the research conducted by [23] revealed that 57 elementary school teachers mastered procedural knowledge more than conceptual knowledge. Then the research conducted by [24] revealed that prospective high school teachers mastered procedural knowledge more than conceptual knowledge. From the results of the two studies, it seems that teachers still have difficulty mastering conceptual knowledge.

In the results of this study, procedural knowledge is higher than conceptual knowledge. The results of this study are supported by the statement [25] that students are weak in conceptual knowledge. In procedural knowledge, students are not required to know the reasons for a concept or process, which is important to know how to use it. Whereas in conceptual knowledge the most important thing is understanding [26]. That way, it is only natural that students still have difficulty mastering conceptual knowledge that requires understanding. Meanwhile, procedural knowledge can be mastered by students only by memorizing work procedures [27]. In the case of biology, for example, students can test food substances on rice using a lugol solution. The experimental results showed positive results, where there was a change in color to blackish blue. If the question arises, can egg whites be tested using the same solution? If students only use memorization in implementing food trial procedures, students will be confused in answering these questions.

\section{CONCLUSION}

The achievement of the conceptual knowledge and procedural knowledge students of class XI state senior high school in Padang city included in the bad category. This's influenced by the teachers' ability to develop both knowledge. Therefore, it's hoped that teachers need to improve teacher professional competence through participation in education and training, conference, workshop, and continuing education to a higher level.

\section{AUTHORS' CONTRIBUTIONS}

1 developed the theory, wrote the manuscript, performed the computations, and carried out the experiment with support from 2. 1 and 2 discussed the results and contributed to the final manuscript.

\section{ACKNOWLEDGMENTS}

Researchers want to say thank you to SMAN 3 Padang, SMAN 5 Padang, SMAN 10 Padang, and SMAN 15 Padang, for supporting this research.

\section{REFERENCES}

[1] S. Aydin, P.U. Keles, M.A. Haşiloğlu, L. Aydin, Academicians' Views on Conceptual and Procedural Learning in Science Education, 
Participatory Educational Research spi16(2) ,2016, 121-129. DOI: http://dx.doi.org /10.17275/per.16.spi.2.13

[2] M.S. Cracolice, J.C. Deming, B. Ehlert, Concept Learning versus Problem Solving: A Cognitive Difference, Journal of Chemical Education 85(6) ,2008, 873-878. DOI: https://doi.org/ 10.1021/ed085p873

[3] B. Rittle-Johnson, M.W. Alibali, Conceptual and Procedural Knowledge of Mathematics: Does One Lead to The Other?, Journal of Educational Psychology 91(1) ,1999, 175-189. DOI: $\quad$ https://doi.org/10.1037/00220663.91.1.175

[4] A. VanScoy, Conceptual and Procedural Knowledge: A framework for Analyzing Pointof-Need Information Literacy Instruction, Communications in Information Literacy 13(2) ,2019, 164-183. DOI: https://doi.org /10.15760/comminfolit.2019.13.2.3

[5] C. Scheibling-Sève, E. Pasquinelli, E. Sander, Assessing Conceptual Knowledge through Solving Arithmetic Word Problems, Educational Studies in Mathematics 103(3) ,2020, 293-311. DOI: https://doi.org/10.1007/s10649-020-09938-3

[6] M. Bekdemir, M. Okur, S. Gelen, The Effects of 2005 Elementary Mathematics Education Curriculum on The Elementary Seventh Grade Students' Conceptual and Procedural Knowledge and Skills, Erzincan Eğitim Fakültesi Dergisi Cilt-Say1 12(2) ,2010, 131147. DOI: http://doi.org/10.17556/jef.05742

[7] J.R. Star, G.J. Stylianides, Procedural and Conceptual Knowledge: Exploring The Gap Between Knowledge Type and Knowledge Quality, Canadian Journal of Science, Mathematics, and Technology Education 13(2) ,2013, 169-181. DOI: https://doi.org /10.1080/14926156.2013.784828

[8] U. Aydin, M. Ozgeldi, The PISA Tasks: Unveiling Prospective Elementary Mathematics Teachers' Difficulties with Contextual, Conceptual, and Procedural Knowledge, Scandinavian Journal of Educational Research 63(1) ,2017, 105-123. DOI: https://doi.org /10.1080/00313831.2017.1324906

[9] H. Zulnaidi, S.N.A.S. Zamri, The Effectiveness of the Geogebra Software: The Intermediary Role of Procedural Knowledge on Students' Conceptual Knowledge and Their Achievement in Mathematics, Eurasia Journal of Mathematics, Science and Technology
Education 13(6) ,2017, 2155-2180. DOI: https://doi.org/10.12973/ eurasia.2017.01219a

[10] M. Levin, Conceptual and Procedural Knowledge During Strategy Construction: A Complex Knowledge Systems Perspective, Cognition and Instruction 36(7) ,2018, 1-31. DOI:

https://doi.org/10.1080/07370008.2018.1464003

[11] U. Aydin, Conceptual and Procedural Angle Knowledge: Do Gender and Grade Level Make a Difference?, International Journal for Mathematics Teaching and Learning 19(1) ,2018, 22-46. Retrieved from file:///C:/Users /ASUS/AppData/Local/Temp/61Article\%20Text-681-2-10-20180830.pdf

[12] K. Achmetli, S. Schukajlow, K. Rakoczy, Multiple Solutions for Real-World Problems, Experience of Competence and Students' Procedural and Conceptual Knowledge, International Journal of Science and Mathematics Education 17(8) ,2018, 16051625. DOI: https://doi.org/10.1007/s10763-0189936-5

[13] U. Wernecke, K. Schütte, J. Schwanewedel, U. Harms, Enhancing Conceptual Knowledge of Energy in Biology with Incorrect Representations, CBE Life Sciences Education 17(1) ,2018, 1-11. DOI: https://doi.org/ 10.1187/cbe. 17-07-0133

[14] C. Förtsch, S. Werner, T. Dorfner, L. von Kotzebue, B.J. Neuhaus, Effects of Cognitive Activation in Biology Lessons on Students' Situational Interest and Achievement, Research in Science Education 47(3) ,2017, 559-578. DOI: https://doi.org/10.1007/s11165-016-9517y

[15] C. Förtsch, T. Dorfner, J. Baumgartner, S. Werner, L. von Kotzebue, B.J. Neuhaus, Fostering Students' Conceptual Knowledge in Biology in the Context of German National Education Standards, Research in Science Education, 50(2) ,2018, 739-771. DOI: https://doi.org/10.1007/s11165-018-9709-8

[16] A.W. Oliveira, E. Johnston, A.O. Brown, Correction to: Exemplification in Undergraduate Biology: Dominant Images and Their Impact on Student Acquisition of Conceptual Knowledge, Canadian Journal of Science, Mathematics and Technology Education 18(358) ,2018, 1-17. DOI: https://doi.org/10.1007/s42330-018-0018-Z

[17] M.A. Al-Mutawah, R. Thomas, A. Eid, E.Y. Mahmoud, M.J. Fateel, Conceptual 
Understanding, Procedural Knowledge and Problem-Solving Skills in Mathematics: High School Graduates Work Analysis and Standpoints, International Journal of Education and Practice 7(3) ,2019, 258-273. DOI: https://doi.org/10.18488/journal.61.2019.73.258 .273

[18] Khaerudin, Kualitas Instrumen Tes Hasil Belajar, Jurnal Madaniyah 2(9) ,2015, 212-235. Retrieved from https://media.neliti.com/media/ publications/195121-ID-kualitas-instrumen-teshasil-belajar.pdf

[19] P. Budsankom, T. Sawangboon, S. Damrongpanit, J. Chuensirimongkol, Factors Affecting Higher Order Thinking Skills of Students: A Meta-Analytic Structural Equation Modeling Study, Educational Research and Reviews 10(19), 2015, 2639-2652. DOI: https://doi.org/10.5897/ERR2015

[20] H.E. Zuya, Prospective Teachers' Conceptual and Procedural Knowledge in Mathematics: The Case of Algebra, American Journal of Educational Research, 5(3) ,2017, 310-315. DOI: http://pubs.sciepub .com/education $/ 5 / 3 / 12$

[21] B. Rittle-Johnson, M. Schneider, Developing Conceptual and Procedural Knowledge of Mathematics, Oxford University Press, 2012.

[22] J.R. Star, Reconceptualizing Procedural Knowledge, Journal for Research in Mathematics Education 36(5), 2005, 404-411. DOI: https://doi.org/10.2307/30034943

[23] K.H. Khashan, Conceptual and Procedural Knowledge of Rational Numbers for Riyadh Elementatry School Teachers, Journal of Education and Human development 3(4), 2014, 181-197. DOI: $\quad$ http://dx.doi.org/ 10.15640/jehd.v3n4a17

[24] J. McGehee, Prospective Secondary Teachers' Knowledge of The Function Concept, University of Texas, 1990.

[25] J. Surif, N.H. Ibrahim, M. Mokhtar, Conceptual and Procedural Knowledge in Problem Solving, Procedia-Social and Behavioral Sciences 56 , 2012, 416-425. DOI: https://doi.org/ 10.1016/j.sbspro.2012.09.671

[26] A. Baki, Educating Mathematics Teachers, Journal of Islamic Academy of Sciences 10(3), 1997, 93-102. Retrieved from https://jag. journalagent.com/ias/pdfs/IAS $10 \quad 3 \quad \begin{array}{llll}10 & 3 & \text { 102.p }\end{array}$ df
[27] J. Hiebert, P. Lefevre, Conceptual and Procedural Knowledge in Mathematics: An Introductory Analysis, Routledge, 1986. 